\title{
Rhode Island branding program for local seafood: Consumer perceptions, awareness, and willingness-to-pay
}

\author{
Nicole L. Richard ${ }^{\mathrm{a}}{ }^{*}$ and Lori F. Pivarnik ${ }^{\mathrm{b}}$ \\ University of Rhode Island
}

Submitted March 14, 2019 / Revised June 7 and August 28, 2019 / Accepted August 28, 2019 /

Published online January 30, 2020

Citation: Richard, N. L., \& Pivarnik, L. F. (2020). Rhode Island branding program for local seafood:

Consumer perceptions, awareness, and willingness-to-pay. Journal of Agriculture, Food Systems, and

Community Development, 9(2), 13-29. https://doi.org/10.5304/jafscd.2020.092.011

Copyright (C) 2020 by the Authors. Published by the Lyson Center for Civic Agriculture and Food Systems. Open access under CC-BY license.

\begin{abstract}
A state brand was created for Rhode Island (RI) seafood in an effort to encourage the development of the fishing and aquaculture industries. Little was done to assess RI consumers, however, regarding their perceptions and understanding of local seafood. Therefore, a survey ( $N=968$ ) of RI consumers at least 18 years old was implemented to assess consumer perceptions, purchasing choices, and understanding of local seafood. The majority of RI consumers, regardless of income, education, and locality, would prefer local seafood if they could easily find it in the market and if they could trust the brand to identify product choices. The top three places to purchase seafood were supermarkets, seafood specialty stores, and restaurants. Seafood quality, taste preference, safety at purchase,

a * Corresponding author: Nicole L. Richard, Food Safety Outreach/Research Program, Department of Fisheries, Animal and Veterinary Science, University of Rhode Island; 530 Liberty Lane; West Kingston, RI 02892 USA; +1-401874-2977; nicolerichard@,uri.edu

b Lori F. Pivarnik, Food Safety Outreach/Research Program, Department of Fisheries, Animal and Veterinary Science, University of Rhode Island; 530 Liberty Lane; West Kingston, RI 02892 USA.
\end{abstract}

and absence of contaminants were considered important or very important factors influencing purchasing decisions; however, respondents felt only somewhat knowledgeable about key seafood attributes. More than half of survey consumers $(66 \%)$ felt that the branding logo, created by the RI Department of Environmental Management, would encourage them to select a local seafood product, and 53\% indicated they would be more willing to try a seafood product if it were labeled local. However, only $12 \%$ of respondents recognized the brand for local RI seafood. This information will be used by state partners to help develop an outreach strategy to promote the RI seafood brand and local seafood and will be used to inform current policy regarding branding.

\section{Keywords}

Seafood, Local Seafood, Local Food, Consumer Behavior, Consumer Preferences, Willingness-toPay, Local Branding Program, State Branding Program

\section{Funding Disclosure}

This study was funded by a grant from National Oceanic and Atmospheric Administration (NOAA)/Rhode Island Sea Grant under agency award no. NA140AR4170082. 


\section{Introduction}

Seafood is a primary source of high-quality protein and contains a variety of nutrients needed for overall health and disease prevention; thus, increased consumption has been recommended (U.S. Department of Health and Human Services [USDHHS] \& U.S. Department of Agriculture [USDA], 2015). The extensive health and nutritional benefits of seafood have been widely reported. Numerous studies have confirmed the positive impact of regular seafood consumption on the reduction of coronary heart disease and for cognitive and vision development (Hicks, Pivarnik, Richard, Gable, \& Morrissey, 2013; McManus, Hunt, Storey, McManus, \& Hilhorst, 2014). While there are some inherent dietary risks associated with the consumption of certain species, particularly for high-risk populations (children, pregnant and nursing mothers, the elderly), the majority of research has shown that seafood consumption benefits greatly outweigh the risks (Hellberg, Dewitt, \& Morrissey, 2012). However, U.S. annual per capita consumption of seafood has been declining or remaining stagnant (National Marine Fisheries Service [NMFS], 2017a), and consumers are not meeting the recommended intake of seafood, particularly seafood containing the omega-3 fatty acids EPA and DHA (Hellberg et al., 2012). Nationwide messaging, while important, may not be as influential as specific programming that targets state-specific consumers, especially in an ocean state such as Rhode Island (RI), which has a significant seafood industry.

In 2015 , the RI seafood industry directly supported over 4,800 jobs, landing revenue close to US\$82 million, sales over US\$347 million, and income of US\$116 million (NMFS, 2017b).

Remarkably, from 85 to $95 \%$ of seafood consumed in the U.S. is imported, and a significant portion caught by U.S. fishers is exported (NMFS, 2017a). The robust RI industry, like the rest of U.S. fisheries, exports the majority of what it catches $(K$. Ayars, Division of Agriculture, RI Dept. of Environmental Management, personal communication, 2015), and Rhode Islanders, along with the rest of U.S. consumers, mainly eat imported fish.

In the U.S., interest in and consumption of local food is growing exponentially (USDA Eco- nomic Research Service [USDA ERS], 2016) propelled by a growing consumer awareness of the benefits of a strong community food system (Dillemuth, 2017; Freedgood \& Fydenkevez, 2017; Johnston, Jai, Phelan, \& Velikova, 2018). The desire for local food-in part due to the perceptions of improved nutrition and food safety, as well as to support local economies, have fresh and more flavorful food, and produce less environmental impact - has fueled the growing interest in local food (Giovannuci, Barham, \& Pirog, 2010). Local governments play an important role in supporting the local food economy. Through the development of targeted strategies and policies, government can support and promote the local food system and impact the economy (Dillemuth, 2017; Freedgood \& Fydenkevez, 2017). In efforts to expand marketing opportunities for local food and support a state's food industry, state branding and marketing campaigns have emerged as a strategy to help food producers differentiate their products by using an official state label (Benson, 2018; French, Cullen, Manalo, \& Jones, 2014; Hullinger \& Tanaka, 2015).

In order to expand local seafood marketing efforts, provide educational opportunities regarding local issues, and increase consumer demand for local seafood, the Rhode Island Seafood Marketing Collaborative (RISMC) was established by the RI state legislature (RI General Laws 20-38, 2011). As an advocacy coalition of academia, industry, and government members, RISMC overall goals were to develop policy initiatives aimed at (1) sustaining and growing the RI seafood industry by increasing the value of RI seafood and of its associated economic benefits, and (2) improving the health and welfare of RI citizens. In support of those goals, key RISMC strategies include increasing consumer awareness of and access to RI seafood, and in turn increasing consumer demand. In an effort to distinguish RI seafood products in the marketplace and seize on the growing movement to "buy local," the collaborative created a RI seafood brand (logo) and codified its use via regulations enacted in 2013 entitled "Rules and Regulations Governing the RI Seafood Brand and Mislabeling of Marine Species" (RIDEM, 2013). The RI Department of Environmental Management (RIDEM) was charged with the legal authority to establish and administer the 
programs to promote seafood products grown and produced in RI. Developing regulations and policy for the term "local" is difficult, since it can be used to describe a variety of marketing or geographical characteristics (Fonner \& Sylvia, 2015; Wilde, 2013); the concept of local seafood is even less well defined (Fonner \& Sylvia, 2015). Local food can have multiple definitions with multiple measures, and it is challenging to find agreement on all the attributes or issues that should be considered (e.g., environmental, geographic, social) (Wilde, 2013). As a policy and regulatory decision, RI or local marine seafood products were considered local if they were grown in RI waters or landed in RI ports by commercial fishers licensed in RI. The brand is authorized for use by licensed RI seafood dealers, but the "chain of custody" can continue through to retail (K. Ayars, personal communication, 2015).

The development of a state brand as a crucial policy centerpiece could benefit the local industry, from harvest to retail (Hullinger \& Tanaka, 2015). Mechanisms must be in place to both protect and foster the integrity of local programs (Giovannucci, Barham, \& Pirog, 2010). However, once the RI seafood brand had been developed and implemented, little was done to assess RI consumers regarding their perceptions and understanding of local seafood. Gauging the attitudes and beliefs of RI consumers concerning seafood, and local seafood specifically, was needed to inform the development and successful implementation of the RI seafood marketing initiative and overall outreach strategy. A 2010 study was conducted at RI farmers markets about consumer preferences for local RI seafood (Grimley \& Roheim, 2010) with results that could have helped direct the brand approach. However, the results of this study, while providing some insight into perceptions regarding seafood, cannot be extrapolated to the larger RI general public that purchases the majority of seafood (and all food) in seafood markets, grocery stores, and restaurants. While the study seemed to indicate a willingness to pay more for fish that was "certified" as being caught by a RI fisherman, customers at farmers markets often pay more for most commodities, so that pricing is not necessarily a motivation for purchasing at this venue. In 2017, the first RI State Food Strategy was released, intended to provide a potential pathway to enhance the climate for food and beverage businesses and to help direct food policy in the state (RI Food Strategy, 2017). The Food Strategy identified the preservation and growth of agriculture and commercial fishery industries as one of five policy focus areas. One specific recommendation was to support the RISMC's efforts to market and grow the RI Seafood brand, recognizing that while RI consumers report that they would prefer seafood landed in RI, they claimed they had a difficult time locating RI caught seafood, even with the logo (RI Food Strategy, 2017). Before an outreach strategy can be developed, it is important to carry out research in order to understand what RI consumers are thinking - their attitudes, concerns, and understanding of local food-and to assess their current purchasing choices and willingness-to-pay (WTP). The research results could be utilized to help encourage industry to promote the brand and, more importantly, could also inform current policy or impact the direction of policy regarding branding.

\section{Methods}

\section{Sampling and Data Collection}

A survey was designed and implemented to measure RI consumer preferences for local seafood following the protocol utilized by Pivarnik and her research colleagues (Hicks, Pivarnik, \& McDermott, 2008; Hicks et al., 2009; 2013; Pivarnik, Richard, Gable, \& Worobo, 2016; Pivarnik, Richard, Patnoad, \& Gable, 2012; Pivarnik et al., 2018). The protocol and questionnaire were approved by the University of Rhode Island Institutional Subjects Review Board. An advisory team helped URI project directors to develop the survey questions. The advisory team consisted of four members, representing the RIDEM, RI Agriculture Partnership, the RI Coastal Resources Management Council, and the University of Rhode Island. All members of the advisory team are also members of the RISMC or the RI Food Policy Council. Prior to implementation, the survey items were reviewed for content validity and clarity. Fourteen experts, solicited from land-grant cooperative extension programs, academic institutions, and the project advisory panel, reviewed the survey. The question- 
naire was revised prior to distribution based on their recommendations. A paper survey was mailed to 5,000 randomly selected households in Rhode Island. The sample of households and their mailing labels were purchased from DirectMail.com (Prince Frederick, MD, USA) and reflected homeowners and renters who were at least 18 years old. The project coordinators considered both paper (mailed) and online survey formats for this project. Online methodologies that were considered included the use of a consumer panel that was available from the online survey clearinghouse; however, it was determined that the RI-specific panel was too small and that therefore this option was not practical. A second option considered was to use email addresses from the direct labeling companies, but consumers often discard random emails without reading them. Therefore, the project directors believed that consumers would be more likely to answer a paper survey with clearly identified university credentials and the possibility of an incentive for their time and effort. The survey was launched in November 2016 and data were collected through the end of December 2016. The mailed survey was administered based on a strategy outlined by Dillman Total Design Method (Salant \& Dillman, 1994). This protocol involved mailing a survey announcement postcard about two weeks prior to the paper survey administration. The survey, along with a self-addressed stamped envelope, was mailed about a week later. The questionnaire contained a letter explaining the project and survey. A second survey reminder postcard was mailed about two weeks later. In an effort to maximize response, a monetary incentive of a US\$100 gift card was offered to 20 randomly selected respondents who chose to enter a lottery-type drawing for surveys returned by the December 20, 2016, deadline (Pivarnik et al., 2018). Of the 5,000 surveys administered, 304 were returned by the postal service due to inadequate addresses. Of the 974 surveys received, six were excluded from analysis (blank, incomplete, or received after the due date). A total of 968 completed surveys were included in the data analysis, with a return rate of $21 \%$.

\section{Questionnaire}

The survey included four sections: background information, behavior and purchasing habits, interpretation of local seafood, and attitudes and sources of information regarding local seafood. The background and demographic section contained questions regarding age, gender, education, race, ethnicity, income, and living situation.

Respondents who indicated that they eat seafood $(n=952)$ answered questions about their seafood consumption and seafood purchasing habits: frequency of consumption, types of seafood eaten, and preferences in purchasing seafood. The interpretation of local seafood section contained questions that elicited respondents' interpretations of local seafood: which seafood species they considered to be local, their interpretation of defining local seafood, their recognition of the "Rhode Island Seafood" logo and its impact on their seafood purchasing and consumption habits. This section also assessed other factors that may influence respondent purchasing decisions to determine how their self-rated knowledge on key seafood topics compared to the issues they considered important to their purchase decisions. Using a 4-point Likert scale (not knowledgeable, somewhat knowledgeable, knowledgeable, very knowledgeable), respondents self-rated their level of knowledge about seafood topics regarding environmental concerns and seafood quality and safe handling practices. They also rated the level of importance that these topics had on their seafood purchasing choices, using a 5 -point Likert scale $(1=$ not important to $5=$ very important). The attitudes and sources of information regarding local seafood section asked respondents to indicate what they believe is the best place to get information about seafood, using a "check all” format. Respondents also rated nine attitude statements related to seafood purchasing and consumption, using a 5-point Likert scale ( $1=$ strongly disagree to $5=$ strongly agree). Except where noted, survey response formats also included multiple choice, check all choices that apply, and yes/no response options.

\section{Data Analysis}

Data analysis was carried out using the SPSS statistical program. Descriptive analysis (e.g., frequencies, percentages, means, and standard deviations), one-way ANOVA followed by the Scheffe post- 
hoc test, and $t$-tests were run. Chi-square statistics were run where the relationships between variables were examined for observed versus expected frequencies. Reliability was tested with Cronbach's alpha measure of internal consistency. For all analysis, the $p$-value for significance was set at $p<.05$; $p<.1$ (but greater than 0.05) was considered to indicate a trend toward significance (Paulin, Lofgren, \&

Table 1. Demographics of Survey Respondents $(N=968)$

\begin{tabular}{|c|c|c|}
\hline & Frequency & $\%$ \\
\hline \multicolumn{3}{|l|}{ Age } \\
\hline 18-24 years & 11 & 1 \\
\hline 25-39 years & 79 & 9 \\
\hline $40-59$ years & 377 & 39 \\
\hline $60-69$ years & 283 & 29 \\
\hline $70+$ years & 210 & 22 \\
\hline \multicolumn{3}{|l|}{ Gender } \\
\hline Male & 550 & 58 \\
\hline Female & 404 & 42 \\
\hline \multicolumn{3}{|l|}{ Highest Level of Education Completed } \\
\hline Less than high school/high school or GED & 15 & 2 \\
\hline High school or GED & 144 & 15 \\
\hline Associate/technical degree/some college & 266 & 28 \\
\hline College degree & 293 & 31 \\
\hline Post-graduate degree & 241 & 25 \\
\hline \multicolumn{3}{|c|}{$\begin{array}{l}\text { Estimated Annual Income (before taxes) for Respondents Who Purchase } \\
\text { Food for THEMSELVES only (US\$) }\end{array}$} \\
\hline Less than $\$ 49,999$ & 126 & 49 \\
\hline Between $\$ 50,000-\$ 79,999$ & 76 & 29 \\
\hline Between $\$ 80,000-\$ 99,999$ & 22 & 9 \\
\hline$\$ 100,000$ or more & 35 & 14 \\
\hline
\end{tabular}

Estimated Annual Income (before taxes) for Respondents Who Purchase Food for Their HOUSEHOLD (US\$)

\begin{tabular}{lrr} 
Less than $\$ 49,999$ & 66 & 12 \\
Between $\$ 50,000-\$ 79,999$ & 106 & 20 \\
Between $\$ 80,000-\$ 99,999$ & 101 & 19 \\
$\$ 100,000$ or more & 267 & 49 \\
\hline Rhode Island County of PRIMARY Residence & & \\
Bristol & 66 & 7 \\
Kent & 204 & 21 \\
Newport & 88 & 9 \\
Providence & 394 & 41 \\
Washington & 209 & 22 \\
\hline
\end{tabular}

Pivarnik, 2017). The specific number of respondents is shown in the tables, indicating where some respondents did not answer the relevant questions.

\section{Results and Discussion}

\section{Demographic Characteristics}

The survey targeted RI residents who were at least 18 years old. Significant demographics of respondents (Table 1) had some discrepancies when compared to U.S. Census data (U.S. Census Bureau, 2016). The distribution of respondents $(N=968)$ by primary county of residence mirrored U.S. Census data for residential distribution in three of the five counties that Rhode Island consists of; respondents from Providence and Washington Counties were under- and over-represented, respectively. Respondents were disproportionately older than the population data reported by the U.S. Census (2016), with a higher representation of $60+$-year-olds (51\% vs. $28 \%$ ) and a lower representation in the 18-24-year age range $(1 \%$ versus $7 \%$ for $20-24$ year-olds). The time of survey implementation (November-December) could have affected the number of respondents in the latter group, since this household population would most likely reflect many short-term renters and college students, i.e., temporary populations that would not participate or were not in residence at the time of survey distribution. The 25-59-year age range for this survey compared favorably to Census data: $48 \%$ versus $58.5 \%$, respectively.

Ninety-nine percent of respondents attained a high school degree or higher, surpassing the 2016 Census estimate of $87 \%$ (U.S. Census Bureau, 2016). However, educational level was higher than the typical RI population, with $56 \%$ having attained a bachelor's degree or higher versus 33\% identi- 
fied by the Census. Concomitant with higher education is the higher than expected income reported by survey respondents $(49 \% \geq \mathrm{US} \$ 100,000$ vs. $27 \%$ Census; $12 \%<$ US $\$ 49,000$ vs. $44 \%$ Census). While there were a few significant differences that could be attributed to income and/or education demographics, they were not universal. However, the demographics of these groups could have influenced survey results such as the frequency of seafood consumption and WTP. Although RI has a high Caucasian population (U.S. Census Bureau, 2016), there was still lower diversity in the population surveyed than expected, with the respondent pool predominantly Caucasian $(93 \%)$ and the African American and Hispanic populations $(\leq 2 \%)$ underrepresented (data not shown).

\section{Seafood Consumption}

Of the $98 \%$ of the respondents who ate seafood, $63 \%$ ate seafood one or more times per week and thus could be considered to be regular or frequent seafood eaters, as defined by Hicks et al. (2008). However, only $36 \%$ ate seafood two or more times per week, as recommended (USDHHS \& USDA, 2015). Table 2 shows the seafood consumption frequency of survey participants. With the exception of the location of primary residence, there were few statistical differences between seafood consumption behavior and the respondent demographic profile. Of the respondents who indicated that they lived on or near the coast, significantly $(p<.05)$ more people ate
Table 2. Frequency of Seafood Consumption among Survey Respondents, Separated by the County of Primary Residence and Self-selection if Residence is on or near the Rhode Island Coast

\begin{tabular}{|c|c|c|c|c|c|}
\hline \multirow[b]{2}{*}{ Demographic } & & \multicolumn{4}{|c|}{ Frequency of seafood consumption (\% of respondents) } \\
\hline & & $\begin{array}{c}\text { Twice per } \\
\text { week or more a }\end{array}$ & $\begin{array}{c}\text { Once } \\
\text { per week }\end{array}$ & $\begin{array}{l}\text { Few times per } \\
\text { month }\end{array}$ & $\begin{array}{c}\text { Once per } \\
\text { month or less }\end{array}$ \\
\hline RI State $(N=936)$ & $(p<.1) b$ & 36 & 27 & 27 & 10 \\
\hline Bristol county $(n=66)$ & & 49 & 29 & 17 & 6 \\
\hline Kent county $(n=194)$ & & 34 & 22 & 33 & 11 \\
\hline Newport county $(n=87)$ & & 40 & 22 & 26 & 12 \\
\hline Providence county ( $n=384$ ) & & 32 & 28 & 30 & 10 \\
\hline Washington county $(n=205)$ & & 37 & 31 & 21 & 11 \\
\hline Live on or near the coast $(N=931)$ & $(p<.05) c$ & & & & \\
\hline Yes $(n=559)$ & & 40 & 28 & 23 & 9 \\
\hline No $(n=372)$ & & 29 & 26 & 33 & 12 \\
\hline
\end{tabular}

a The 2015-2020 Dietary Guidelines for Americans, issued by the U.S. Department of Health and Human Services (HHS) and the USDA, recommend that Americans eat seafood twice a week.

b Chi-square analysis indicated data trends toward significance at $p<.1$.

c Chi-square analysis indicated a significant relationship at $p<.05$. 
seafood, with $46 \%$ considered frequent seafood eaters (one or more times per week), but that only $22 \%$ ate the recommended amount (Hicks et al., 2008). A 2017 survey conducted in Connecticut showed that $91 \%$ indicated they ate seafood, and $35 \%$ were considered to be regular or frequent seafood eaters, but only $15 \%$ ate the recommended amount (Benson, 2018). The higher percentage of seafood consumption among RI consumers could be due to the fact that Rhode Island, nicknamed the "Ocean State," has the second-highest ratio of shoreline (feet) to land area (square miles) among U.S. states $\left(1,312 \mathrm{ft} . / \mathrm{mi}^{2}\right)$, while Connecticut ranked eighth $\left(589 \mathrm{ft} . / \mathrm{mi}^{2}\right)$ (U.S. Census Bureau, 2011, Table 360).

\section{Places to Purchase Seafood}

The top three places to purchase seafood, of the eight options listed in the survey, are shown in Table 3. The top three, as first or second choices, were supermarkets, seafood specialty stores, and restaurants. The top choice, supermarkets, was driven by the choices of the more inland and/or urban Kent and Providence Counties $(p<.05)$, which accounted for over $60 \%$ of the respondent pool. As expected, RI counties nearer to the sea (i.e., Bristol and Newport) had a higher frequency of people who indicated that their first choice was a seafood specialty store. However, respondents who self-identified that they felt they lived on or near the coast $(n=554)$ indicated that the supermarket $(36 \%)$ was also their first choice to purchase seafood. This was due to Washington County residents composing a higher respondent pool and to the county, including about a third of its area away from the coastline. Also, a 2017 survey of seafood consumers in Connecticut identified the same top three places to purchase seafood: local seafood market $(29 \%)$, grocery store (28\%), and restaurant (23\%) (Benson, 2018). Similarly, a survey conducted by the Atlantic Corporation (2019) found that supermarkets accounted for the most popular place $(51 \%)$ to purchase seafood to eat at home. Purchase-site preferences would be critical to targeting RI consumers regarding local seafood and seafood consumption, as shoppers tend to be loyal to their supermarket (Skallerud, Korneliussen, \& Olsen, 2009).

\section{Places to Get Information About Seafood}

Improving marketing campaigns for seafood involves a multifaceted approach that includes the development of trust in sources of information, confidence in the evaluation of the quality and preparation of fish, along with the importance of fish and the perceived potential risk of consuming it (Carlucci et al., 2015). Table 4 shows the top choices, of the 12 items listed in the survey, for places to get information about seafood: point-ofpurchase at a seafood specialty store $(56 \%)$, family or friends $(40 \%)$, cookbooks $(38 \%)$, and point-ofpurchase at a supermarket (31\%). Although seafood specialty store was among the top three places to purchase seafood, it was not the overall first or second choice averaged for all respondents and urban areas. However, this may reflect the fact that while consumers may purchase their seafood at a grocery store for convenience, they might think that information may be better at a seafood specialty store. Food choice and purchase decisions have been linked to habitual behavior (Carlucci et al., 2015; Christenson, O'Kane, Farmery, \& McManus, 2017; McManus et al., 2014) and are

Table 3. Top Three Places to Purchase Seafood, Ranked First and Second Choice

\begin{tabular}{|c|c|c|c|c|c|c|c|c|}
\hline \multirow[b]{3}{*}{ Places to Purchase Seafood } & \multicolumn{8}{|c|}{ Percent (\%) of Respondents } \\
\hline & \multicolumn{2}{|c|}{ All Respondents } & \multicolumn{5}{|c|}{ First Choice by County of Primary Residence } & \multirow{2}{*}{$\begin{array}{c}\text { First Choice } \\
\text { by Live } \\
\text { on/near the } \\
\text { Coast } \\
(n=554)\end{array}$} \\
\hline & $\begin{array}{l}\text { First Choice } \\
\qquad(n=934)\end{array}$ & $\begin{array}{l}\text { Second } \\
\text { Choice } \\
(n=845)\end{array}$ & $\begin{array}{l}\text { Bristol } \\
\text { County } \\
(n=63)\end{array}$ & $\begin{array}{l}\text { Kent County } \\
\quad(n=192)\end{array}$ & $\begin{array}{l}\text { Newport } \\
\text { County } \\
(n=85)\end{array}$ & $\begin{array}{c}\text { Providence } \\
\text { County } \\
(n=381)\end{array}$ & $\begin{array}{c}\text { Washington } \\
\text { County } \\
(n=206)\end{array}$ & \\
\hline Restaurant & 13 & 39 & - & - & - & - & - & - \\
\hline Seafood Specialty Store & 28 & 16 & 33 & - & 32 & - & 33 & - \\
\hline Supermarket & 41 & 32 & - & 47 & - & 46 & 33 & 36 \\
\hline
\end{tabular}


Table 4. Top Choices for Places to Get Information about Seafood, for the State of Rhode Island and by the Respondents' County of Primary Residence

\begin{tabular}{lcccc}
\hline & \multicolumn{3}{c}{ Percent $(\%)$ of Respondents } \\
\cline { 2 - 5 } Demographic & $\begin{array}{c}\text { Point of Purchase: } \\
\text { Seafood Store }\end{array}$ & Family and Friends & Cookbook & $\begin{array}{c}\text { Point of Purchase: } \\
\text { Supermarket }\end{array}$ \\
\hline Rhode Island State $\left(N=652^{\text {a }}\right)$ & 56 & 40 & 38 & 31 \\
Bristol County $(n=41)$ & 59 & 42 & 49 & 34 \\
Kent County $(n=139)$ & 50 & 36 & 40 & 32 \\
Newport County $(n=64)$ & 59 & 50 & 41 & 25 \\
Providence County $(n=265)$ & 57 & 46 & 37 & 34 \\
Washington County $(n=139)$ & 57 & 34 & 43 \\
\hline
\end{tabular}

a Respondents who indicated exactly three top choices, as asked in the survey, were included in the data. Those who indicated fewer or more than three choices were excluded.

influenced by trustworthy sources (Birch \& Lawley, 2012; Giampietri, Verneau, Del Giudice, Carfora, \& Finco, 2018). Thus, it is not surprising that stores that specialize in seafood, and family and friends, ranked high among preferred sources of information about seafood. However, the survey choices did not include healthcare providers, such as dieticians, as a group that has been considered a reliable information source, as indicated by other research (Hicks et al., 2013; International Food Information Council [IFIC] Foundation, 2018).

\section{Factors Influencing Seafood Purchasing}

Issues relating to seafood quality $(97 \%)$, taste preference $(93 \%)$, seafood safety at purchase $(92 \%)$, and contaminants in seafood (91\%) were important or very important factors for seafood purchasing choices (Table 5). However, respondents felt only somewhat knowledgeable about seafood quality and contaminants in seafood. In addition, respondents had lower knowledge confidence concerning seafood selection, preparation, and handling. Issues relating to seafood origin, seafood sustainability, and consumption advisories were considered important by over $70 \%$ of respondents, while selfrated knowledge was low. These are reasons often cited as barriers to seafood consumption. However, the barriers tend to have a stronger impact on those who consume less seafood (Birch \& Lawley, 2012). Hicks et al. (2008) showed that consumers considered to be frequent eaters more often ate seafood at home, reflecting more knowledge regarding handling and preparation. Therefore, with $63 \%$ of respondents considered regular or frequent eaters in this study, higher confidence regarding handling would be expected. Of the 81\% of respondents who felt knowledgeable about the health benefits of seafood, statistical analysis showed that $53 \%$ were considered regular or frequent seafood eaters (data not shown), with only $31 \%$ eating the recommended amount of seafood (two or more servings per week) (USDHHS \& USDA, 2015) and $22 \%$ eating one serving per week.

The nutritional value of seafood alone does not appear to be the only driver to increase consumer seafood consumption. A positive attitude toward the health benefits of seafood has not been found to be a sufficient indicator of intention to eat seafood (Carlucci et al., 2015; Christenson et al., 2017; Thong \& Solgaard, 2017). Overall, respondents did not feel very knowledgeable about key seafood attributes. While taste, nutritional value, and quality are considered important factors influencing seafood purchase and consumption (Birch \& Lawley, 2012; Hicks et al., 2008; Olsen, 2003, 2004), low knowledge has been associated with a lack of confidence in making seafood purchasing decisions (Hicks et al., 2008; Olsen, 2003, 2004; Sterling et al., 2015; Verbeke, Vermeir, \& Brunso, 2017). Product familiarity and knowledge have been shown to have a positive correlation with consumer confidence in evaluating seafood and making informed purchasing decisions (Birch \& 
Table 5. Self-rated Knowledge with Level of Importance on Purchasing Habits of Seafood Topics among Rhode Island Consumer Respondents

\begin{tabular}{|c|c|c|c|c|}
\hline \multirow[b]{2}{*}{ Seafood Topics } & \multicolumn{2}{|c|}{$\begin{array}{c}\text { Self-Rated Knowledge a } \\
\text { 4-point Scale } \\
(N=905-929)\end{array}$} & \multicolumn{2}{|c|}{$\begin{array}{l}\text { Level of Importance }^{b} \\
\text { 5-point Scale } \\
(N=919-930)\end{array}$} \\
\hline & $\begin{array}{c}\text { Average Score } \pm \\
\text { Standard Deviation }\end{array}$ & $\begin{array}{c}\text { Knowledgeable + } \\
\text { Very Knowledgeable } \\
\text { (\% respondents) }\end{array}$ & $\begin{array}{c}\text { Average Score } \pm \\
\text { Standard Deviation }\end{array}$ & $\begin{array}{c}\text { Important + } \\
\text { Very Important } \\
\text { (\% respondents) }\end{array}$ \\
\hline Seafood quality & $2.7 \pm 0.8$ & 62 & $4.7 \pm 0.6$ & 97 \\
\hline Contaminants in seafood & $2.2 \pm 0.8$ & 30 & $4.5 \pm 0.8$ & 91 \\
\hline Seafood safety at purchase & - & - & $4.5 \pm 0.7$ & 92 \\
\hline Taste preference & - & - & $4.5 \pm 0.7$ & 93 \\
\hline Safe seafood handling practices & $2.9 \pm 0.8$ & 73 & $4.3 \pm 0.9$ & 84 \\
\hline Health benefits from eating seafood & $3.1 \pm 0.7$ & 81 & $4.3 \pm 0.8$ & 87 \\
\hline Selecting seafood at a market & $2.8 \pm 0.8$ & 63 & $4.1 \pm 0.8$ & 83 \\
\hline Environmental concerns & - & - & $4.0 \pm 1.0$ & 76 \\
\hline Preparing seafood & $3.0 \pm 0.8$ & 74 & $4.0 \pm 0.9$ & 77 \\
\hline Where the seafood comes from (origin) & $2.3 \pm 0.9$ & 38 & $4.0 \pm 0.9$ & 76 \\
\hline Sustainable seafood & $2.1 \pm 0.9$ & 32 & $4.0 \pm 0.9$ & 73 \\
\hline Purchasing convenience & - & - & $3.9 \pm 1.5$ & 75 \\
\hline Fish consumption advisories & $2.1 \pm 0.9$ & 35 & $3.9 \pm 1.0$ & 70 \\
\hline Access and availability & - & - & $3.9 \pm 1.0$ & 77 \\
\hline Household member preference & - & - & $3.9 \pm 1.0$ & 75 \\
\hline Price & - & - & $3.9 \pm 0.9$ & 71 \\
\hline Food Allergies & - & - & $3.5 \pm 1.5$ & 59 \\
\hline Eco-labeled seafood products & $1.7 \pm 0.8$ & 15 & $3.4 \pm 1.0$ & 46 \\
\hline
\end{tabular}

a Average score calculated from a 4-point Likert scale: 1=Not Knowledgeable, 2=Somewhat Knowledgeable, 3=Knowledgeable, 4=Very Knowledgeable.

b Average score calculated from a 5-point Likert scale: 1=Not Important, 2=Somewhat Important, 3=Neutral, 4=Important, 5=Very Important.

Lawley, 2012; Hicks et al., 2008). A review by Richter and Klöckner (2017) showed that consumers' familiarity with sustainable seafood labels increased their willingness to purchase compared to consumers not familiar with the labels. Therefore, any brand or logo indicating local RI seafood would require strategies to educate the consumer about its meaning.

Studies have shown that consumers may consider brand name and price as extrinsic indicators of product quality (Boulding \& Kirmani, 1993; Dodds, Monroe, \& Grewal, 1991; Verbeke et al., 2017), especially when they lack the knowledge and confidence on their own to evaluate seafood quality and other characteristics. The role of trust in influencing consumer food purchasing decisions may offset negative perceptions (Giampietri et al., 2018) and low knowledge (Giampietri et al., 2018;
Grebitus, Steiner, \& Veeman, 2015). Enhanced trust could be facilitated by the development of a familiar, trusted brand (Birch \& Lawley, 2012; Campbell \& Goldstein, 2001; Lobb, Mazzocchi, \& Traill, 2007).

\section{Purchasing Local Seafood}

Tables 6 to 9 and Figure 1 show RI consumer perceptions regarding purchasing local RI seafood, and the RI brand logo and WTP for local seafood. Personal factors shape food choices. Understanding these traits can help to improve promotion, communication, product perception, and distribution (Thong \& Solgaard, 2017). Therefore, investigating RI consumer perceptions will enhance outreach and marketing strategies regarding local seafood and branding. Initially, respondents were queried concerning the fresh seafood species most 
commonly eaten and which species they considered local (data not shown). The top 10 species (of 31 listed in the survey) most commonly eaten by respondents were shrimp $(74 \%)$, canned tuna $(66 \%), \operatorname{cod}(66 \%)$, clams (59\%), scallops (58\%), lobster (54\%), haddock (52\%), salmon, wild and aquacultured (47\% and $40 \%$ ), flounder (35\%), and swordfish (34\%). Shrimp, salmon, canned tuna, cod, and clams are seafood products that are favored by consumers nationally and compose the top 10 frequently consumed species, ranging in 2016 from 4.10 lbs. (1.86 kg.) per person (shrimp) to $0.34 \mathrm{lbs}$. $(0.15 \mathrm{~kg}$ ) per person (clams) (National Fisheries Institute [NFI], 2017). Scallops, while not on the national top ten list, were close behind the most frequently consumed kinds of seafood at 0.214 lbs. $(0.10 \mathrm{~kg})$ per capita, as calculated from national fisheries statistics (NMFS, 2017a).

While RI consumers indicated that they would prefer to purchase local seafood products $(4.2 \pm$ 0.8 ) and order at local restaurants $(4.1 \pm 0.9)$ (Table 6), their purchasing habits do not strongly align with these preferences. Shrimp and salmon ranked as the most consumed species, but they are never local options although $20 \%$ considered shrimp to be a locally caught product. Clams and lobsters are local products, however, and the other commonly eaten seafood is seasonal. Although sea scallops are seasonally local, bay scallops are never local to RI; nevertheless, $56 \%$ considered bay scallops local. RI is the second-largest U.S. harvester of squid and accounts for the highest percentage of landings along the East Coast (NMFS, 2017a, 2017b). In fact, squid (calamari) is the RI official state appetizer (RI Secretary of State, 2014). However, squid is consumed by only $33 \%$ of respondents and was considered local by only $32 \%$. Scup, which is always local, was hardly eaten and only $18 \%$ considered it local. In part, this could be attributed to difficulty in finding local seafood in the market (3.2 $\pm 1.0)$ and that sales personnel and wait staff are not highly knowledgeable, since the respondents appeared to think that local seafood was only slightly safer or of higher quality (3.4 \pm 0.9 and 3.6 \pm 0.9 , respectively). The desire for local seafood could provide opportunities to develop consumer knowledge and retail marketing strategies for local seafood products. The RI branding program was designed to increase consumer awareness regarding the identification of local seafood and seasonal availability; however, consumers have different perceptions of local, and without an outreach strategy, local brands would be of little use.

\section{Defining "Local Seafood"}

When respondents were queried about their interpretation of the term "local seafood," the majority defined it as having been caught within RI state waters (3-mile or 4.8-km limit; 68\%) and aquacultured or farm-raised in RI waters (55\%) (Table 7). While the latter comports with the definition of local as codified in RI state statutes and pertains to

Table 6. Rhode Island Consumer Attitudes Related to Seafood Purchasing and Consumption ( $N=920-927)$

\begin{tabular}{lc}
\hline Items & $\begin{array}{c}\text { Average Score a } \pm \\
\text { Standard Deviation }\end{array}$ \\
\hline I prefer to buy local seafood & $4.2 \pm 0.8$ \\
I prefer to order seafood at local restaurants rather than larger chain or franchise restaurants & $4.1 \pm 0.9$ \\
Local seafood is higher quality than other seafood at the market & $3.6 \pm 0.9$ \\
Buying local seafood is more important than price & $3.5 \pm 1.0$ \\
Local seafood is safer than other seafood at the market & $3.4 \pm 0.9$ \\
It is easy to find local seafood in the market & $3.2 \pm 1.0$ \\
Sales personnel at the retail counters are knowledgeable about seafood & $3.2 \pm 0.9$ \\
Waitresses/waiters at restaurants are knowledgeable about seafood & $2.8 \pm 0.9$ \\
As long as seafood is sold in RI, I consider it local & $2.2 \pm 1.1$ \\
\end{tabular}

a Average score was calculated from a 5-point Likert scale: 1=Strongly Disagree, 2=Disagree, 3=Neither Disagree nor Agree, 4=Agree, $5=$ Strongly Agree. 
Table 7. Rank Order of Rhode Island Consumer Interpretation of "Local Seafood" ( $N=9^{9}{ }^{\text {a) }}$

\begin{tabular}{lcc}
\hline Fish or Shellfish Species & Frequency & $\%$ \\
\hline Caught within Rhode Island (RI) state waters (the 3-mile limit) & 644 & 68 \\
Aquacultured or farm-raised in RI waters & 517 & 317 \\
Landed in a New England port & 267 & 34 \\
Caught anywhere and by any fisher as long as it is landed in a RI port & 195 & 28 \\
Caught anywhere as long as it is caught by a RI licensed fisher & 178 & 17 \\
Landed in RI ports only & 102 & 19 \\
Caught by RI licensed fishers but landed in another state port and trucked to RI & 73 & 39 \\
Landed in a Northeast (Virginia to Maine) port & 39 & 19 \\
Sold in Rhode Island, regardless of where or by whom the fish was caught & 19 \\
Other & & 2 \\
\hline
\end{tabular}

Respondents checked all that applied.

a Of the respondents who indicated that they eat seafood ( $N=952), 11$ respondents did not answer this question.

the RI branding logo (RI General Laws, Section 20-38-1), the former does not. A Rhode Island seafood product means "any marine species that have been grown in RI waters by commercial aquaculturists and any marine species that have been landed in RI by commercial fishers, pursuant to all applicable state and federal regulations" (RIDEM, 2013, Rule 5.00 Definitions). When queried if they understood the definition, $90 \%$ agreed; however, only $60 \%$ agreed that the definition reflected their concept of "local seafood" and only $61 \%$ felt that this definition was a good reflection of what local means (Table 8 ). This could be a barrier to increasing the consumption of local RI seafood products. Understanding how RI consumers interpret "local" seafood is important to building trust through branding and helping to develop a policy direction through which to promote RI seafood.

\section{Branding "Local Seafood"}

The RI Seafood brand is overseen and guided by the RISMC and administered by RIDEM (2013). However, only $23 \%$ of respondents indicated that they trusted the state government to administer the brand (data not shown). RI consumers did not appear to have much trust in any one organization or group to accurately administer the RI local seafood brand: consumer group (29\%), independent third party $(27 \%)$, or industry $(18 \%)$. Trust in the certifying body is critical to consumer acceptance of labelled products (Richter \& Klöckner, 2017). While lack of trust could be a potential barrier to increasing consumption of local RI seafood products through a branding program, lack of consumer recognition of the RI Seafood branding logo was a bigger factor: only $12 \%$ of respondents recognized the logo and $27 \%$ were unsure if they recognized the logo (Table 9). Familiarity with the RI local

\section{Table 8. Consumer Interpretation of the "Rhode Island Seafood Products" Branding Definition aper Legislation $\left(N=943-946^{b}\right)$}

\begin{tabular}{llccc}
\hline & & \multicolumn{3}{c}{ Percent (\%) of Respondents } \\
\cline { 3 - 5 } Definition of "Rhode Island Seafood Products" & Yes & \multicolumn{2}{c}{ No Unsure } \\
\hline Understand the definition of “local RI seafood products" & $(N=946)$ & 90 & 2 & 8 \\
Definition reflects consumer concept of “local seafood" & $(N=943)$ & 60 & 27 & 13 \\
Definition is a good reflection of meaning of "local seafood" & $(N=943)$ & 61 & 23 & 16 \\
\hline
\end{tabular}

a "Rhode Island Seafood Products" means any marine species that have been grown in RI waters by commercial aquaculturists and any marine species that have been landed in RI by commercial fishers, pursuant to all applicable state and federal regulations (RIDEM, 2013, Rule 5.00 Definitions).

b Of the respondents who indicated that they eat seafood $(N=952)$, four to nine respondents did not answer these questions. 
seafood label is important to building consumer trust and acceptance of the products. Two-thirds of respondents $(66 \%)$ felt that the logo would encourage them to select a local seafood product and $53 \%$ indicated that they would be more willing to try a seafood product if it were labeled local. There was clearly an increased trend in all communities to be willing to try a new seafood product if it were labeled local, and respondents living on or near the coast in regions having significantly $(p<.05)$ more people $(57 \%)$ would be more willing to try a new seafood species if it were labeled local. A consumer study in Connecticut showed that $24 \%$ preferred seafood from Connecticut, whereas almost half of respondents (45\%) did not have a preference (Benson, 2018). Other studies have shown that Australian consumers strongly preferred "local" fish to imported products and one of the top reasons for consuming less seafood was the lack of local seafood varieties
(Christenson et al., 2017; Daneberg \& Mueller, 2011).

Overall, $72 \%$ of RI consumers were WTP more money to purchase a "local" white fish over a similar, less expensive "non-local" seafood product (Table 9), with females significantly more likely $(p<.05)$ than expected to pay more (data not shown). This agrees with other published information, reported by Richter \& Klöckner (2017), that indicated females purchase more organic and seafood products. For respondents who indicated that they live on or near the coast, significantly $(p<.05)$ more than expected $(75 \%)$ indicated they would be WTP more money to purchase a "local" white fish. While Providence County, an urban community with lower median income was significantly lower, two-thirds $(68 \%)$ still indicated willingness to consider paying more for local. Forty-two percent of respondents were willing to spend US $\$ 1.00$ more per pound for a local fish of similar quality if the

Table 9. "Rhode Island Seafood" Branding Logo: Consumer Recognition of the Logo and its Influence on their Seafood Consumption and Purchasing Choices

\begin{tabular}{|c|c|c|c|c|c|c|c|}
\hline \multirow[b]{3}{*}{ "Rhode Island Seafood" Branding Logo } & \multicolumn{7}{|c|}{ Percent (\%) of Respondents } \\
\hline & \multirow{2}{*}{$\begin{array}{c}\text { Rhode Island } \\
\text { State } \\
(N=948-947)\end{array}$} & \multirow{2}{*}{$\begin{array}{c}\text { Live on } / \text { near } \\
\text { Coast } \\
(N=557-564)\end{array}$} & \multicolumn{5}{|c|}{ Rhode Island County } \\
\hline & & & $\begin{array}{c}\text { Bristol } \\
(N=64-66)\end{array}$ & $\begin{array}{c}\text { Kent } \\
(N=196-197)\end{array}$ & $\begin{array}{l}\text { Newport } \\
(N=85-87)\end{array}$ & $\begin{array}{c}\text { Providence } \\
(N=379-384)\end{array}$ & $\begin{array}{c}\text { Washington } \\
(N=204-207)\end{array}$ \\
\hline \multicolumn{8}{|l|}{ Recognition of the logo } \\
\hline Yes & 12 & 12 & 14 & 12 & 9 & 13 & 11 \\
\hline No & 61 & 59 & 58 & 65 & 53 & 64 & 58 \\
\hline Unsure & 27 & 29 & 28 & 23 & 38 & 23 & 31 \\
\hline \multicolumn{8}{|c|}{ Logo encouragement on selection of seafood for purchase and/or consumption } \\
\hline Encourages & 66 & 68 & 66 & 72 & 70 & 62 & 67 \\
\hline No Effect & 21 & 18 & 15 & 18 & 13 & 25 & 20 \\
\hline Unsure & 13 & 13 & 19 & 10 & 17 & 13 & 13 \\
\hline \multicolumn{8}{|c|}{ Willingness to try a new seafood species if labeled local } \\
\hline Only willing to try if labeled local & 14 & 13 & 11 & 16 & 9 & 14 & 12 \\
\hline More willing to try if labeled local & 53 & $57^{\mathbf{a}}$ & 52 & 51 & 67 & 49 & 58 \\
\hline $\begin{array}{l}\text { Does not matter, would try new } \\
\text { seafood species, labeled local or not }\end{array}$ & 22 & $19^{a}$ & 25 & 21 & 14 & 26 & 20 \\
\hline $\begin{array}{l}\text { Not willing to try any new seafood, } \\
\text { labeled local or not }\end{array}$ & 11 & 11 & 12 & 12 & 9 & 11 & 10 \\
\hline \multicolumn{8}{|c|}{ Willingness to pay more money for a local "white" fish that is the same quality as a similar, non-local "white" fish } \\
\hline Willing to pay & 72 & $75^{a}$ & 73 & 70 & 76 & $68^{a}$ & $79^{a}$ \\
\hline
\end{tabular}

a Chi-square analysis indicated a significant relationship at $p<.05$ within the branding logo subheadings and among demographic categories. 
non-local fish costs US\$7.99/lb., and 36\% were willing to spend US\$1.00 more per pound if the non-local fish costs US\$14.99/1b. (Figure 1). As indicated previously, the respondent pool consisted of educated participants with higher than expected income, and the data should be considered in that context. Specifically, education had an impact on WTP, with respondents with at least a bachelor's degree significantly more likely than expected $(p<.05)$ to pay more money for local products. However, there did appear to be an overall WTP if RI consumers knew that the fish was local, although cost is often considered a barrier to seafood consumption (Hicks et al., 2008). Willingnessto-pay information helps assess demand for local seafood. However, there are limitations for extrapolation from this study. Directly asking participants their WTP under various hypothetical scenarios could reflect possible purchase intentions, but may not reflect actual purchase behavior. What people say they are WTP and what they actually pay may differ by as much as 50\% (French et al., 2014). This study provides clear evidence of WTP for local RI seafood by RI consumers throughout the state, but behavior assessment, not in the scope of this project, could be a next step.

\section{Promoting RI Local Seafood}

The results of this survey were presented to the RISMC. The presentation reinforced the emerging perception that the RI Seafood brand was not fully achieving its intended purpose. While it constituted a potentially useful way to distinguish RI seafood products in the marketplace, insufficient consumer outreach and education limited its effectiveness. At the most recent meeting of the collaborative, in 2019, there was a general consensus that the logo, while perhaps appropriate as an official seal, was not working well as a brand, since it was not conveying the Rhode Island local seafood message in a way that readily resonates with consumers $(R$. Ballou, RI Dept. of Environmental Management, personal communication, 2019). The collaborative has therefore agreed to pursue the development of a new brand, consider loosening the regulatory restrictions on its use so that it can better serve as an all-encompassing ambassador for RI seafood, and enhance efforts to develop and implement an

Figure 1. Respondent Willingness to Pay Additional Money for Local Fish of Similar Quality Over Non-local Fish

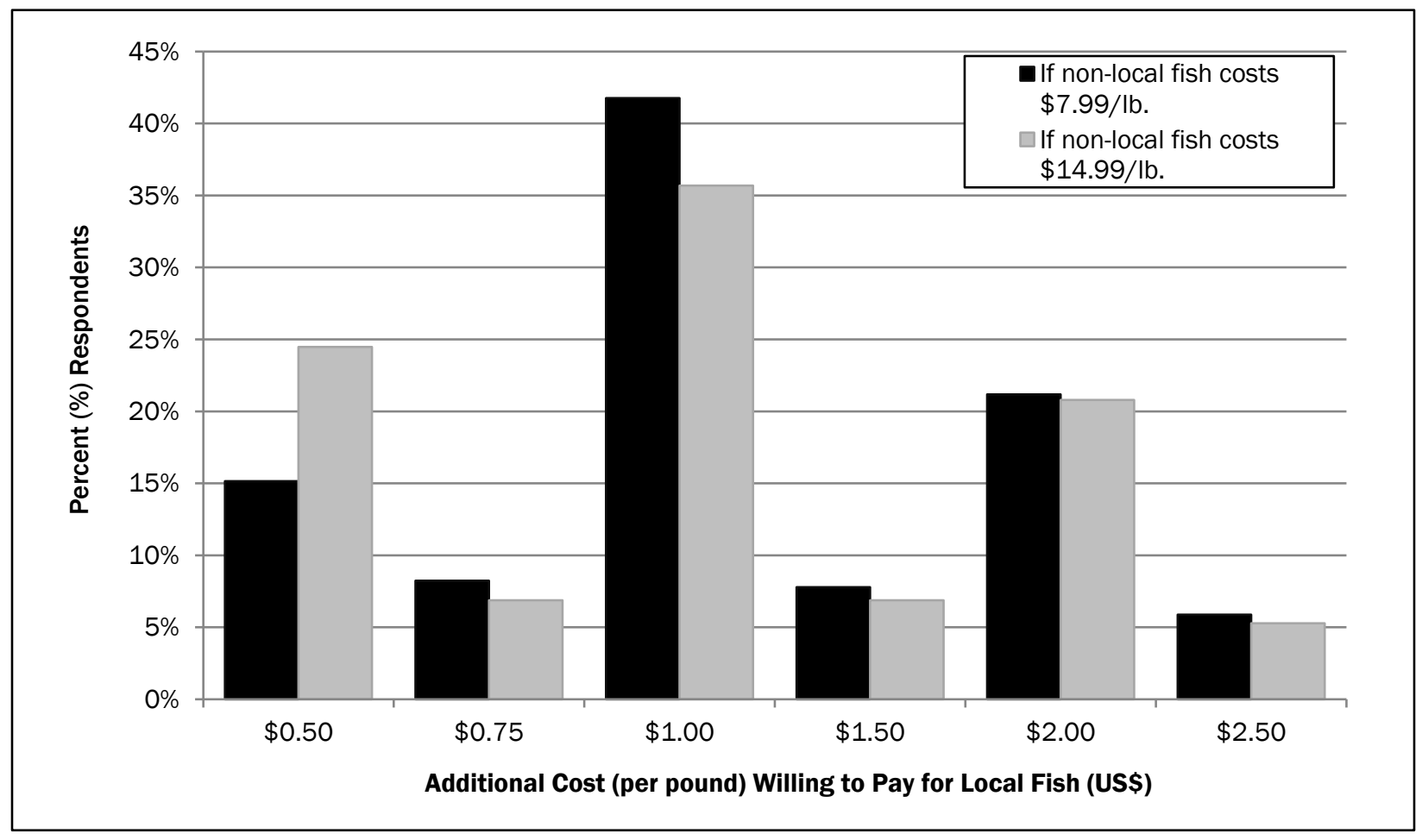


effective outreach strategy. These key policy objectives are a direct consequence of the survey results (R. Ballou, personal communication, 2019).

\section{Conclusion}

This study assessed consumer perceptions of local seafood, as well as purchasing choices and willingness-to-pay. The majority of RI consumers, regardless of income, education, and locality, would prefer local seafood if they could easily find it in the market and if they could trust the brand (i.e., logo) to identify product choice. A trusted local brand that consumers could recognize could positively influence consumer seafood purchasing decisions and thus aid in sustaining the local seafood industry.

The results of this study, which have been presented to and well received by stakeholders, have helped to establish a critical baseline for consumer perceptions and awareness of local seafood, and WTP. Thus, these results have influenced the policy direction of the local brand. However, the local RI seafood brand has not lived up to its potential in that it has not had a major influence on seafood consumers, as the study results indicate. There is an emerging consensus on the part of the RISMC that the brand should be redesigned and repurposed to render it more effective. At the same time, there is increasing recognition that a more robust public information and outreach program needs to be developed and implemented in RI to better address the strong consumer preferences for local seafood affirmed by this study. RI is well-positioned to act on the results of this study by stepping up efforts, via the RISMC, to better link the supplies of local seafood products with the documented consumer interest in such products. Such efforts could, and should, lead to the sustained economic growth of the RI seafood industry as well as the improved health of
RI citizens. The results of this work will be integral in informing new directions for a more successful program. It will impact future discussions by informing the process and help influence policy efforts.

Consumer interest in and WTP for local seafood coupled with a known branding program could support a stronger local seafood industry. Working through the RISMC and in accordance with the RI Food Strategy, the results of the study will be used to help develop and implement a more effective outreach strategy to achieve the abovenoted policy objectives pertaining to RI seafood. Based on this research, the easiest communities to target initially would be the coastal communities at both supermarkets and specialty seafood stores. Consumers must be educated as to what the brand means and how it is defined in an effort to build trust; there must be both consumer awareness to help facilitate the purchase of local seafood and regulatory modifications to encourage processors, retailers, and restaurateurs to use it. This may not alter the high desirability of shrimp and salmon, but it could encourage consumers to purchase more local seafood, given their willingness to try local species and pay a little more money for it.

\section{Acknowledgments}

The project coordinators would like to thank the project advisory board for their expertise and significant contributions to the development of the survey: Ken Ayers, Chief, Division of Agriculture, RI Dept. of Environmental Management; David Butel, Aquaculture Coordinator, RI Coastal Resources Management Council; and Dr. Hiro Uchida, Environmental and Natural Resource Economics, University of Rhode Island. The authors would also like to thank Dr. Robert Gable for providing his expertise in evaluation and statistical assessment.

\section{References}

Atlantic Corporation. (2019). Measuring consumer attitudes and preferences about farm-raised shellfish, finfish, and sea vegetables in the Atlantic coast states. Waterville, Maine: Author. Retrieved from https://www.atlanticcorp.us/

Benson, J. (2018). Too few residents taking advantage of local seafood bounty: Survey is start of efforts to encourage more consumption. Sea Grant Connecticut Wracklines, 18(1), 11-12. Retrieved from https://seagrant.uconn.edu/wp-content/uploads/sites/1985/2018/05/Seafood.survey.pdf

Birch, D., \& Lawley, M. (2012). Buying seafood: Understanding barriers to purchase across consumption segments. Food Quality and Preference, 26(1), 12-21. https://doi.org/10.1016/j.foodqual.2012.03.004 
Boulding, W., \& Kirmani, A. (1993). A consumer-side experimental examination of signaling theory: Do consumers perceive warranties as signals of quality? Journal of Consumer Research, 20(1), 111-123. https://doi.org/10.1086/209337

Campbell, M. C., \& Goldstein, R. C. (2001). The moderating effect of perceived risk on consumers' evaluations of product incongruity: Preference for the norm. Journal of Consumer Research, 28(3), 439-449. http://dx.doi.org/10.1086/323731

Carlucci, D., Nocella, G., Devitiis, B., Viscecchia, R., Bimbo, F., \& Nardone, G. (2015). Consumer purchasing behavior towards fish and seafood products: Patterns and insights from a sample of international studies. Appetite, 84, 212227. https://doi.org/10.1016/j.appet.2014.10.008

Christenson, J. K., O’Kane, G. M., Farmery, A. K., \& McManus, A. (2017). The barriers and drivers of seafood consumption in Australia: A narrative literature review. International Journal of Consumer Studies, 41(3), $299-311$. https://doi.org/10.1111/ijcs.12342

Daneberg, N., \& Mueller, S. (2011). Omnibus consumer research findings - Wave 2. Deakin, ACT: Australian Seafood Cooperative Research Center, UniSA Ehrenberg-Bass Institute for Marketing Science. Retrieved from https://www.seafoodcrc.com/southern-bluefin-tuna/consumer-research/2008-779-omnibus-consumer-researchfindings-wave-2.html

Dillemuth, A. (2017). Community food production: The role of governments in increasing community food production for local markets (Planning \& Policy Brief). Washington, D.C.: U.S. Department of Agriculture, National Institute of Food and Agriculture \& Growing Food Connections. Retrieved from http://growingfoodconnections.org/wpcontent/uploads/sites/3/2015/11/GFCFoodProductionPlanningPolicyBrief 2017August29.pdf

Dodds, W. B., Monroe, K. B., \& Grewal, D. (1991). Effects of price, brand and store information on buyers' products evaluations. Journal of Marketing, 28(3), 307-319. https://doi.org/10.2307/3172866

Fonner, R., \& Sylvia, G. (2015). Willingness to pay for multiple seafood labels in a niche market. Marine Resource Economics, 30(1), 51-70. https://doi.org/10.1086/679466

Freedgood, J., \& Fydenkevez, J. (2017). Growing local: A community guide to planning for agriculture and food systems. Northampton, MA: American Farmland Trust. Retrieved from http://www.farmlandinfo.org/growing-local-community-guide-planning-agriculture-and-food-systems

French, C., Cullen, K., Manalo, A. \& Jones, E. (2014). Consumer and retailer demand for local seafood: Opportunities in the N.H. marketplace (Pub. No. UNHMP-IS-SG-14-010). Durham: University of New Hampshire Cooperative Extension, New Hampshire Sea Grant College Program. Retrieved from https://seagrant.unh.edu/sites/seagrant.unh.edu/files/media/pdfs/extension/alternative seafood marketing.pdf

Giampietri, E., Verneau, F., Del Giudice, T., Carfora, V., \& Finco, A. (2018). A theory of planned behavior perspective for investigating the role of trust in consumer purchasing decision related to short food supply chains. Food Quality and Preference, 64, 160-166. https://doi.org/10.1016/j.foodqual.2017.09.012

Giovannucci, D., Barham, E., \& Pirog, R. (2010). Defining and marketing "local” foods: Geographical indications for US products. Journal of World Intellectual Property, 13(2), 94-120. https://doi.org/10.1111/j.1747-1796.2009.00370.x

Grebitus, C., Steiner, B., \& Veeman, M. (2015). The roles of human values and generalized trust on stated preferences when food is labeled with environmental footprints: Insights from Germany. Food Policy, 52, 84-91. https://doi.org/10.1016/i.foodpol.2014.06.011

Grimley, S., \& Roheim, C. (2010). Assessing the market potential for "local" seafood in Rhode Island: Qualitative results of a survey of consumers'preferences and perceptions (RI Sea Grant report). Narragansett: University of Rhode Island, RI Sea Grant.

Hellberg, R. S., Dewitt, C. A., \& Morrissey, M. T. (2012). Risk-benefit analysis of seafood consumption: A review. Comprehensive Reviews in Food Science and Food Safety, 11(5), 490-517. https://doi.org/10.1111/j.1541-4337.2012.00200.x

Hicks, D., Pivarnik, L. F., \& McDermott, R. (2008). Consumer perceptions about seafood_An internet survey. Journal of Foodservice, 19(4), 213-226. https://doi.org/10.1111/j.1748-0159.2008.00107.x

Hicks, D., Pivarnik, L. F., McDermott, R., Richard, N. L., Hoover, D. G., \& Kniel, K. E. (2009). Consumer awareness and willingness to pay for high-pressure processing of ready-to-eat food. Journal of Food Science Education, 8(2), 32-38. https://doi.org/10.1111/j.1541-4329.2009.00069.x 
Hicks, D., Pivarnik, L. F., Richard, N. L., Gable, R., \& Morrissey, M. (2013). Assessing knowledge and attitudes of US healthcare providers about benefits and risks of consuming seafood. Journal of Food Science Education, 12(4), 75-80. https://doi.org/10.1111/1541-4329.12014

Hullinger, A. M., \& Tanaka, K. (2017). Agriculture of the middle participation in state branding campaigns: The case of Kentucky. Journal of Agriculture, Food Systems, and Community Development, 6(1), 107-120. https://doi.org/10.5304/jafscd.2015.061.008

International Food Information Council (IFIC) Foundation. (2018). 2018 Food and health survey. Washington, D.C.: Author. Retrieved from https://www.foodinsight.org/2018-food-and-health-survey

Johnston, N. E., Jai, T. M., Phelan, K. V., \& Velikova, N. (2018). Branding state-level pride: Exploring values and attitudes of local food product consumption. Journal of Foodservice Business Research, 21(6), 659-681. https://doi.org/10.1080/15378020.2018.1531740

Lobb, A. E., Mazzocchi, M., \& Traill, W. B. (2007). Modelling risk perception and trust in food safety information within the theory of planned behavior. Food Quality and Preference, 18(2), 384-395. https://doi.org/10.1016/j.foodqual.2006.04.004

McManus, D., Hunt, W., Storey, J., McManus, J., \& Hilhorst, S. (2014). Perceptions and preference for fresh seafood in an Australian context. International Journal of Consumer Studies, 38(2), 146-152. https://doi.org/10.1111/ijcs.12076

National Fisheries Institute (NFI). (2017, November 2). Top 10 list highlights seafood consumption progress. McLean, Virginia: Author. Retrieved from https://www.aboutseafood.com/press release/top-10-list-highlights-seafood-consumption-progress

National Marine Fisheries Service (NMFS). (2017a). Fisheries of the United States, 2016 Report. Washington, D.C.: U.S. Department of Commerce, National Oceanic and Atmospheric Administration. Retrieved from https://www.fisheries.noaa.gov/resource/document/fisheries-united-states-2016-report

National Marine Fisheries Service (NMFS). (2017b). Fisheries economics of the United States, 2015 (NOAA Tech. Memo. NMFS-F/SPO-170). Silver Spring, MD: U.S. Department of Commerce, National Oceanic and Atmospheric Administration, NMFS. Retrieved from https://www.st.nmfs.noaa.gov/economics/publications/feus/fisheries economics 2015/index

Olsen, S. O. (2003). Understanding the relationship between age and seafood consumption: The mediating role of attitude, health involvement, and convenience. Food Quality and Preference, 14(3), 199-209. https://doi.org/10.1016/S0950-3293(02)00055-1

Olsen, S. O. (2004). Antecedents of seafood consumption behavior. An overview. Journal of Aquatic Food Product Technology, 13(3), 79-91. https://doi.org/10.1300/J030v13n03 08

Paulin, C., Lofgren, I. E., \& Pivarnik, L. F. (2017). An assessment of consumer food safety handling practices of produce at grocery stores in Rhode Island. Food Protection Trends, 37(2), 99-106. Retrieved from https://pdfs.semanticscholar.org/8656/847cf1651501c62b78da8ef92ab0b19694ed.pdf

Pivarnik, L. F., Richard, N. L., Gable, R. K., \& Worobo, R. (2016). Knowledge and attitudes of produce and seafood processors and food safety educators regarding nonthermal processes. Journal of Food Science Education, 15(4), 120128. https://doi.org/10.1111/1541-4329.12093

Pivarnik, L. F., Richard, N. L., Hirsch, D., Becot, F., Conner, D., \& Parker, J. (2018). Small- and medium-scale New England produce growers' knowledge, attitudes and implementation of on-farm food safety practices. Food Protection Trends, 38(3), 156-170. Retrieved from https://pdfs.semanticscholar.org/8915/cece567651053cc6ed7bae77be3c6638030e.pdf

Pivarnik, L. F., Richard, N. L., Patnoad, M. S., \& Gable, R. K. (2012). Assessment of food safety knowledge for managers of residential childcare institutions (RCCI) in the Northeast. Food Protection Trends, 32(6), $296-308$. Retrieved from http://www.foodprotection.org/files/food-protection-trends/Jun-12-Gable.pdf

Rhode Island Food Strategy. (2017). Rhode Island Food Strategy: An actionable vision for food in Rhode Island. Providence: RI Commerce Corporation. Retrieved from http://dem.ri.gov/relishrhody/pdf/rifood17.pdf

Rhode Island General Laws, 20-38. (2011). The Rhode Island Seafood Marketing Collaborative of 2011. Providence: Rhode Island General Assembly. Retrieved from http://webserver.rilin.state.ri.us/Statutes/title20/20-38/INDEX.HTM 
Rhode Island Department of Environmental Management (RIDEM). (2013). Rules and regulations governing the Rhode Island seafood brand and the mislabeling of marine species. Providence: RIDEM, Division of Agriculture. Retrieved from https://risos-apa-production-public.s3.amazonaws.com/DEM/7861.pdf

Rhode Island Secretary of State. (2014). Rhode Island state symbols. Providence: RISOS. Retrieved from http://sos.ri.gov/divisions/civics-and-education/reference-desk/ri-state-symbols

Richter, I. G. M., \& Klöckner, C. A. (2017). The psychology of sustainable seafood consumption: A comprehensive approach. Foods, 6(10), 86-100. https://doi.org/10.3390/foods6100086

Salant P., \& Dillman, D. A. (1994). How to conduct your own survey. New York: John Wiley.

Skallerud K., Korneliussen, T., \& Olsen, S. O. (2009). An examination of consumers' cross-shopping behavior. Journal of Retailing and Consumer Studies, 16(3), 181-189. https://doi.org/10.1080/08961530.2014.848081

Sterling B., Gooch, M., Dent, B., Marenick, N., Miller, A., \& Sylvia, G. (2015). Assessing the value and role of seafood traceability from an entire value-chain perspective. Comprehensive Reviews in Food Science and Food Safety, 14(3), $205-268$. https://doi.org/10.1111/1541-4337.12130

Storey M., Forshee, R. A., Anderson, P. A., \& Miller, S. A. (2006). Communicating risk-risk to the public: The case of the bealth benefits and risks from eating seafood (Ceres White Paper). College Park: University of Maryland, Center for Food, Nutrition, and Agricultural Policy. Retrieved from http://wealthandhealth.ltd.uk/articles/Seafood Risks Benefits.pdf

Thong, N. T., \& Solgaard, H. S. (2017). Consumer's food motives and seafood consumption. Food Quality and Preference, 56, 181-188. https://doi.org/10.1016/j.foodqual.2016.10,008

U.S. Census Bureau. (2011). Statistical abstract of the United States 2011. Section 6: Geography and environment. Retrieved from https://www2.census.gov/library/publications/2010/compendia/statab/130ed/tables/geo.pdf

U.S. Census Bureau. (2016). 2012-2016 American Community Survey 5-year estimates. Retrieved from https://www.census.gov/acs/www/data/data-tables-and-tools/data-profiles/2016/

U.S. Department of Agriculture, Economic Research Service (USDA ERS). (2016). Local foods. overview. Washington, D.C.: Author. Retrieved from https://www.ers.usda.gov/topics/food-markets-prices/local-foods.aspx

U.S. Department of Health and Human Services \& U.S. Department of Agriculture. (2015). 2015-2020 dietary guidelines for Americans (8th ed). Washington, D.C.: Authors. Retrieved from http://health.gov/dietaryguidelines/2015/guidelines/

Verbeke W., Vermeir, I., \& Brunso, K. (2017). Consumer evaluation of fish quality as basis for fish market segmentation. Food Quality and Preference, 18(4), 651-661. https://doi.org/10.1016/i.foodqual.2006.09.005

Wilde, P. (2013). Food policy in the United States: An introduction. New York: Routledge. 